\title{
The Effect of Leadership and Motivation on Employee Performance
}

\author{
Linzzy Pratami Puyri ${ }^{1}$, Hazmanan Khair Pasaribu ${ }^{2}$ \\ \{linzzypratami@umsu.ac.id ${ }^{1}$, hazmanankhair@umsu.ac.id² \\ University of Muhammasiyah Sumatera Utara, Medan, Indonesia
}

\begin{abstract}
This study aims to determine and analyze the influence of leadership and motivation on employee performance at PT Harian Waspada Medan. In this study using an associative approach that looks for the relationship between leadership and motivation on the performance of employees with the object of research are permanent employees at PT Harian Waspada Medan. Testing is done by Multiple Regression by passing the classic assumption test first, then testing the hypothesis partially with $\mathrm{t}$ test and simultaneous with Test $\mathrm{f}$. Then look for the coefficient of determination to see how much the percentage of the variance in the independent variable affects the dependent variable. The results of the study state that partially and simultaneously both independent variables have a positive and significant effect on employee performance and the value of the variation of the coefficient of determination is the remaining $47.6 \%$ is influenced by other variables not examined in this study.
\end{abstract}

Keywords: Leadership, Motivation, and Employee Performnace.

\section{Introduction}

The success of an organization or company is largely determined by its human resources (HR), because humans become planners, actors, and determinants of the goals of a company. In an effort to achieve organizational goals the company depends on the utilization of existing resources, especially its human resources. Availability of capital, technology and other resources has not been a guarantee for the achievement of company objectives. In this case the role of HR determines the success of a company, because the success or failure of a company depends on the ability or quality of human resources in carrying out its activities. HR activities can be carried out well if the performance is also good. Performance is a result of work achieved by a person in carrying out tasks that are charged to him based on skills, experience and sincerity as well as the time specified.

Performance (work performance) is the work quality and quantity achieved by an employee in carrying out their duties in accordance with the responsibilities given to him[1]. Good performance will not be obtained by the company. There are many factors that can affect employee performance. In general there are two factors that can affect employee performance, namely internal factors and external factors. Internal factors of the company are usually sourced from within the employee, for example the ability, ability, dexterity and accuracy in carrying out a task that is charged to him. Meanwhile, external factors of the company are sourced from the environment around where employees work, for example, work environment, compensation, external motivation, company policies and the attitude of leaders in the company. 
In general, the performance problems that often occur in the company come from external factors, namely, leadership problems and employee motivation. Leadership is an activity to know the behavior of others, or art influences human behavior both individuals and groups [2]. Motivation can be interpreted as a driving force that causes people to do something or do something for fear of something. In leadership companies it is important to improve employee performance, because under good leadership, someone will be able to work better, as well as motivation, an employee who has high motivation to work will increase his enthusiasm which will ultimately improve his performance PT. HARIAN WASPADA is a company engaged in newspapers. In this company there are problems found by the author as long as the writer carries out the prariset. The problem in this company comes from a lack of good coordination between leaders and subordinates in carrying out the company's operational activities. This happens because in the leader company is not communicating with subordinates either just asking about the work that has been completed or not done, so that when subordinates find it difficult to do their work, the employee is more silent and neglects his duties than to ask his boss which in turn causes a decrease in motivation and employee performance.

The results of research conducted by Syazhashah and Inggrid [3] state that there is an influence of leadership and motivation on employee performance. Then research conducted by Jelita, et al [4] the results of his research stated that leadership and motivation affect employee performance.

\section{Literatur Review}

\subsection{Performance}

Performance is the result of work that has a strong relationship with the organization's strategic objectives. Consumer satisfaction and economic contribution. Thus, performance is about doing work and the results achieved from the job [5].

Performance is the result of work that has a strong relationship with the organization's strategic objectives. Consumer satisfaction and economic contribution. Thus, performance is about doing work and the results achieved from the job [1].

\subsection{Leadreship}

Leadership comes from English, namely "Leadership". Leadership is defined as the ability to influence and mobilize others so that they are willing and able to follow the wishes of management or the company in order to achieve goals that have been predetermined effectively and efficiently.

Leadership is a natural growth of people who associate for goals in a group [6]. Leadership is science and art influencing people or groups to act as expected to achieve goals effectively and efficiently [7]. Leadership is a job carried out by a leader in an organization or company, where the task is to organize and coordinate subordinates to be willing to follow and carry out their obligations as desired for the achievement of company goals.

\subsection{Motivation}


Motivation is the driving force for humans to do things in accordance with the goals they have planned, which can be sourced from within themselves or from others and their environment.

Motivation is an impetus for a series of processes of human behavior on achieving goals, while the elements contained in motivation include elements of arousing, directing, maintaining towards intensity, being continuous and having goals [8]. Motivation is a process that explains individual intensity, direction, and effort perseverance towards achieving goals.

\subsection{Research Purposes}

This research aims to:

1. to analyze the influence of leadership on employee performance

2. to analyze the influence of motivation on employee performance

3. to analyze the influence of leadership and motivation on employee performance.

\subsection{Hypothesis}

Hypothesis of this research are:

1. there is an influence of leadership on employee performance

2. there is an influence of motivation on employee performance

3. there is influence of leadership and motivation on employee performance

\section{Research Methods}

This research uses associative research which is to see the effect of independent variables with the dependent variable namely leadership and motivation on employee performance. Testing the hypothesis in this study using multiple regression analysis. Multiple regression analysis in this study was used to determine the effect of leadership and motivation on employee performance. The population is all employees of PT Harian Waspada Medan totaling 230 employees. Determination of the sample used is to use the solvin formula, with the aim to get a sample that can describe and represent the population. From the total population with an inaccuracy level of $10 \%$, then using the formula above obtained a sample of 70 employees

\section{Research Result And Discussion}

\subsection{Descriptive Statistics}

\section{Leadership}

1. The survey results show the majority of respondents' answers were distributed to the Strongly Agree answers as many as 43 people or $(61.4 \%)$ for the statement that your Leader has good knowledge and skills as a leader.

2. The survey results show that the majority of respondents' answers are distributed to the Disagree answer, which is 42 people or $(60 \%)$ for the statement that your leader has good skills in managing operational activities.

3. The survey results show the majority of respondents' answers are distributed to the Strongly Agree answers that is as many as 43 people or $(61.4 \%)$ for the statement that 
your Leader has a good suggestion or idea for each job that is difficult to do becomes easier.

4. The survey results show the majority of respondents' answers were distributed to the Strongly Agree answers that is as many as 43 people or $(61.4 \%)$ for the statement that your Leader has a good renewal to change operational activities to be more effective and efficient.

5. The survey results show the majority of respondents' answers were distributed to the Strongly Agree answer as many as 44 people or (61.4\%) for the statement that your Leader has a high initiative in every job he does.

6. The survey results show that the majority of respondents answered answers to the Strongly Agree answer that is 41 people or (58.6\%) for the statement that your Leader prefers to do the work that can be done by himself without having to bother his employees.

7. The survey results showed the majority of respondents' answers were distributed to the Strongly Agree answers as many as 43 people or (61.4\%) for the statement that your Leader has good responsibility for each operational activity.

8. The survey results show the majority of respondents' answers were distributed to the Strongly Agree answers as many as 43 people or (61.4\%) for the statement that your Leader has good responsibility for each employee he leads.

9. The survey results show the majority of respondents' answers were distributed to the Strongly Agree answer as many as 44 people or $(62.9 \%)$ for the statement that your Leader has a solid work activity.

10. The survey results show the majority of respondents' answers were distributed to the Strongly Agree answer as many as 44 people or (62.9\%) for the statement that your Leader has a solid work activity.

11. The survey results show the majority of respondents' answers were distributed to the Strongly Agree answers, namely as many as 43 people or $(61.4 \%)$ for the statement that the policies and rules set by your leader are the best for the company.

12. The survey results show the majority of respondents' answers were distributed to the Strongly Agree answer as many as 42 people or $(60.0 \%)$ for the statement that the policies and regulations set by your leader are always accompanied by reward and punishment.

\section{Motivation}

1. The survey results show respondents' answers to statements received salaries in line with the work done, the majority of respondents answered as much as 44 people or $(62.9 \%)$.

2. The survey results show respondents' answers about the statement of the salary that was given had met the standards, the majority of respondents answered that there were as many as 45 people or $(64.3 \%)$.

3. The survey results show respondents' answers to the statement The company gave a guarantee of safety, the majority of respondents answered as many as 43 people agreed or $(61.4 \%)$.

4. The survey results show respondents' answers to the statement felt comfortable and safe at work, the majority of respondents answered as many as 43 people agreed or $(61.4 \%)$.

5. The survey results show respondents' answers to the statements always appreciated employees who made achievements, the majority of respondents answered as many as 44 people or $(62.9 \%)$. 
6. The survey results show respondents' answers to the statement received an appreciation for the increase in work, the majority of respondents answered as many as 42 people agreed $(60.0 \%)$.

7. The survey results show respondents' answers to statements provided good facilities and accommodations, the majority of respondents answered as many as 44 people or $(62.9 \%)$.

8. The survey results show respondents' answers to the statement that the company had provided sufficient facilities, the majority of respondents answered agreed as many as 42 people or $(60.0 \%)$.

\section{Performance}

1. The majority of respondent's answers were distributed to the Strongly Agree answer as many as 44 people or $(62.9 \%)$ for the statement that the work done by employees was in accordance with the standards set.

2. The majority of respondent's answers were distributed to the Strongly Agree answer as many as 44 people or $(62.9 \%)$ for the statement that the work done by the employee was better than the predetermined standard.

3. Respondents' majority answers were distributed to the Strongly Agree answer as many as 44 people or $(62.9 \%)$ for the statement that the work that employees do is more than the standard set.

4. The majority of respondent's answers were distributed to the Strongly Agree answers as many as 45 people or $(64.3 \%)$ to the statement that the amount of work done by employees in accordance with the standards that have been determined.

5. The majority of respondents' answers were distributed to the Strongly Agree answer, namely 44 people or $(62.9 \%)$ for the statement that the work that the employee did was completed on time.

6. The majority of respondents' answers were distributed on the Very Agree answer, namely as many as 43 people or $(61.4 \%)$ for the statement that the work done by the employee was faster than the time specified.

7. The majority of respondents' answers were distributed to the Strong Agree answers, namely 41 people or $(58.6 \%)$ to the statement that the Employees were always present on time.

8. The majority of respondents' answers were distributed on the Very Agree answer as many as 45 people or $(64.3 \%)$ for the statement that the employee attendance percentage was higher than the percentage of employee absence.

9. The majority of respondents' answers were distributed on the Very Agree answer, namely as many as 43 people or $(61.4 \%)$ for the statement that the Employees were able to work together well among fellow employees.

10. The majority of respondents' answers were distributed to the Strongly Agree answers, namely 41 people or $(58.6 \%)$ to the statement that the Employees were more concerned with group interests than personal interests.

\subsection{Results}

Table 1. Hypothesis Results Coefficients $^{a}$ 


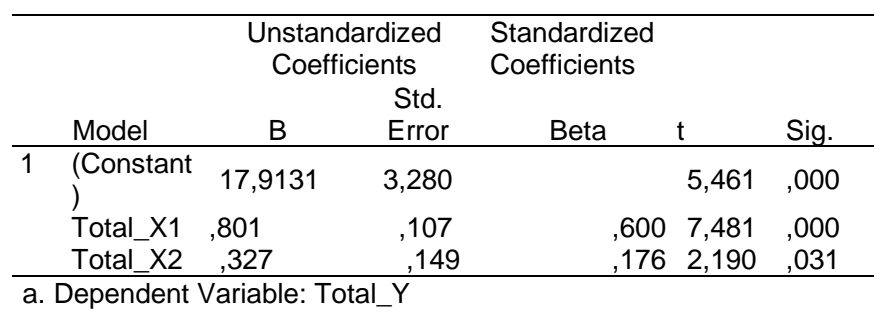

From the table above it can be concluded that:

1. For the value of leadership on employee performance, the results of processing shows that the value of $t$ count is 7.481 (tcount $7.481<t$ table 1.9844 ) and the value of sig $0.000<0.05$. Thus it can be concluded that leadership has a positive and significant effect on employee performance.

2. For the value of motivation on employee performance, the results of the processing show that the value of tcount is 2.190 (tcount $2.190<\mathrm{t}$ table 1.9844) and the sig value is 0.031 $<0.05$. Thus it can be concluded that motivation has a positive and significant effect on employee performance.

Table 2. Hypothesis Results

\begin{tabular}{|c|c|c|c|c|c|c|}
\hline \multicolumn{7}{|c|}{ ANOVA $^{a}$} \\
\hline \multirow{2}{*}{\multicolumn{2}{|c|}{ Model }} & Sum of & & Mean & & \\
\hline & & Squares & Df & Square & $\mathrm{F}$ & Sig. \\
\hline \multirow[t]{3}{*}{1} & Regression & 2906,060 & 2 & 1453,030 & 44,133 &, $000^{\mathrm{b}}$ \\
\hline & Residual & 3193,650 & 97 & 32,924 & & \\
\hline & Total & 6099,710 & 99 & & & \\
\hline
\end{tabular}

From the results of the above processing it can be seen that the calculated probability value is 44,133 (F count 44,133> Ftable 3,09) and sig value $0,000<0,05$, thus it can be concluded that all independent variables have a significant and significant effect on employee performance.

This research is in line with the research conducted by Rion and Kurniawaty [9]. The results of his research stated that both partially and simultaneously leadership and motivation affect employee performance.

Furthermore, research conducted by Jelita, et al [4] the results of his research stated that simultaneously leadership and motivation affect employee performance. Leadership is a style or attitude that is shown by superiors to subordinates and becomes an example for their subordinates. Leadership is an initiative to act that produces a consistent pattern in order to find a solution to a common problem / activity to influence people to be directed towards achieving organizational goals [10].

This is also in line with the opinion of Anoraga [11] which gives an understanding of motivation is the giving or emission of motives. Or it can be interpreted as a matter or condition to be a motive. While work motivation is someone's drive to do work. So it can be concluded 
that with the high motivation of employees to do work, the employee's performance will increase along with the motivation they have.

Leadership and motivation are two things that are very close and play an important role in employee performance. With good leadership, the employees will be motivated to do the work as they are exemplified by their leaders. This is the motivation for employees to improve their performance.

\section{Conclusions}

Based on the above research results it can be concluded that:

a. There is a leadership influence on employee performance

b. There is a motivational effect on employee performance

c. There is an influence of leadership and motivation on employee performance

\section{Acknowledgements}

Thank you to all those who helped. Thank you very much to Mr. Chancellor of UMSU along with his staff and Mr. Chairman of LP2M and all supporting parties

\section{References}

[1] Mangkunegara A.A. Anwar Prabu (2011). Company Human Resources Management, Bandung, PT Remaja Rodaskarya, Tenth Printing

[2] Thoha, Miftah. (2010). Leadership in Management, Jakarta, PT Raja Grafindo Persada, First Edition. Fourteenth Printing

[3] Syazhasah and Inggrid (2015). Influence of Ability and Work Motivation on Employee Performance. Journal of Accounting, Economics and Business Management. Vo.3 No. 2 2015, Pp. 135-141

[4] Jelita, et al (2016). Effect of Leadership and Work Motivation on Employee Performance at PT Amanah Finance in Manado. The Periodic Journal of Efficiency. Vol. 16. No.02, Pp. 459-47

[5] Wibowo (2009). Performance Management, Jakarta, Rajawali Press, Second Edition. Third print

[6] Terry, Goerge and Lesile W. Rue (2010). Darsar-basic Management, Jakarta, PT Bumi Aksara, Indonesian Edition, Eleventh Mold

[7] Usman, Husaini (2010). Management Theory, Practice, and Educational Research, Jakarta, PT Bumi Aksara, Third Edition, Second Printing

[8] Wibowo (2009). Performance Management, Jakarta, Rajawali Press, Second Edition. Third print.

[9] Rion and Kurniawaty (2014). Influence of Leadership and Motivation on Employee Performance at the Department of Transportation, Communication and Information, Pekanbaru City. Economic Journal. Vol. 22 No. 2. Pp. 110 - 121

[10] Thoha, Miftah (2004). Management Leadership, PT Raja Grafindo Perkasa, Jakarta

[11] Anoraga, Pandji (2005). Business management. Third print. Jakarta, Rineka Cipta 